Research Article

Patricia Martín*, F. Xavier Oms

\title{
Early Neolithic Husbandry in the Pre-Pyrenean Area. The Management of Herds at the Cova Colomera (Serra del Montsec, Spain) and Its Implications for the Early Occupation of the Region
}

https://doi.org/10.1515/opar-2020-0190

received November 20, 2020; accepted June 20, 2021

\begin{abstract}
The Cova Colomera is located in the pre-Pyrenees, at a central point of a set of natural paths traditionally used by shepherds for herd movements. The Early Neolithic occupations documented in this cave (5250-4780 cal. BC) make it a key point for understanding the beginning of husbandry in the area. In this work, we present a zooarchaeological study of the macrofaunal remains recovered from these Early Neolithic occupations of the Cova Colomera. As observed at other sites in the region, the herds that occupied the Cova Colomera were mainly composed of domestic sheep and goats, raised for their milk and meat. Cattle, as well as a variety of wild animals, served as a food supplement and a source of secondary resources. The low number of recovered remains is interpreted as evidence of the low intensity and/or short duration of the occupations, which would have taken place at different times of the year, mainly in spring and autumn. This suggests that the Cova Colomera was used as a transient settlement during the movement of flocks. The data corroborate the idea that the natural resources of the pre-Pyrenees were exploited by the earliest shepherds in the Early Neolithic.
\end{abstract}

Keywords: husbandry implementation, domestic caprines, seasonality, sheepfold cave

\section{Introduction}

Husbandry has been a traditional activity in the Pyrenean region, conditioning the life of the people in the area, not only economically but also culturally and in their relationship with the natural environment,

Special Issue: THE EARLY NEOLITHIC OF EUROPE, edited by F. Borrell, I. Clemente, M. Cubas, J. J. Ibáñez, N. Mazzucco, A. Nieto-Espinet, M. Portillo, S. Valenzuela-Lamas, \& X. Terradas

\footnotetext{
* Corresponding author: Patricia Martín, Seminari d’Estudis i Recerques Prehistòriques (SERP), Departament d'Història i Arqueologia, Universitat de Barcelona, C/Montalegre 6, 08001, Barcelona, Spain; Institut de Paleoecologia Humana i Evoluciò Social (IPHES-CERCA), Zona Educacional 4, Campus Sescelades URV (Edifici W3), 43007 Tarragona, Spain; Àrea de Prehistòria, Universitat Rovira i Virgili (URV), Facultat de Lletres, Avinguda Catalunya, 35, 43002 Tarragona, Spain, e-mail: patrimr9@gmail.com

F. Xavier Oms: Seminari d'Estudis i Recerques Prehistòriques (SERP), Departament d'Història i Arqueologia, Universitat de Barcelona, C/Montalegre 6, 08001, Barcelona, Spain, e-mail: xavieroms@gmail.com ORCID: Patricia Martín 0000-0002-8781-7966
} 
especially its geographical and climatic features, its diversity, and the availability of natural resources (Miralles \& Tutusaus, 2005; Violant i Simorra, 1985, 2001).

The Pyrenees are a mountainous system that reaches a maximum altitude of 3,404 m a.s.l. (Aneto Peak). The pre-Pyrenean area is located on the southern slopes of the Pyrenees; its valleys and mountains range between 600 and just over 2,000 $\mathrm{m}$ a.s.l.

The oldest recorded evidence of husbandry in the Pyrenean region dates from around the beginning of the second half of the sixth millennium BC (e.g. Alcalde, Bosch, \& Buxó, 1991; Gassiot Ballbè et al., 2017; Geddes, 1983; Martín \& Vaquer, 1995; Oms, Petit, Morales, \& García, 2012; Utrilla \& Laborda, 2018). This is only slightly later than the oldest evidence of husbandry in the Mediterranean area (e.g. Cortés et al., 2012; Esquembre et al., 2008; García-Puchol, Diez Castillo, \& Pardo-Gordó, 2017; Oms et al., 2016). In turn, it is slightly older than the earliest evidence of farming settlements in subalpine areas (over 1,500 $\mathrm{m}$ a.s.l.), which dates from the final third of the sixth millennium BC (Clemente-Conte et al., 2016; Gassiot et al., 2014; Orengo, Palet, Ejarque, Miras, \& Riera, 2014; Rojo et al., 2013).

The short time lapse between all these dates shows the rapid spread of husbandry in the inland areas of the Iberian Peninsula, where it probably followed the river courses (Oms et al., 2012). Although zooarchaeological studies of Neolithic assemblages from the Pyrenees are still scarce, this early husbandry shows similar features both in the coast and the inland, based on sheep and goat breeding, with percentages always exceeding $30 \%$, and often as high as $80 \%$ of NISP (number of identified specimens), and complemented with cattle and domestic pig breeding (e.g. Antolín, Navarrete, Saña, Viñerta, \& Gassiot, 2018; Castaños, 2004; Saña, Antolín, Alcántara, Sierra, \& Tornero, 2020; Sierra, Bréhard, Montes, Utrilla, \& Saña, 2019; Tejedor-Rodríguez et al., 2021).

The earliest farmers in the Pyrenean region occupied the territory using various settlement strategies. Both open-air and cave settlements have been documented, with agriculture and husbandry implemented to different degrees (Antolín et al., 2018; Gassiot Ballbè et al., 2017), and showing different functionalities, especially within the caves (storage, sheepfold, habitat, etc.).

From the perspective of the land occupation by the Neolithic herders, the recent study of the Cova de Els Trocs has documented the practice of altitudinal movements of sheep in the Cova de Els Trocs (Bisaurri, Huesca, 1,564 m a.s.l.), since the late 6th-millennium cal. BC, using $\delta^{18} \mathrm{O}$ and $\delta^{13} \mathrm{C}$ stable isotope analyses (Tejedor-Rodríguez et al., 2021). Previous studies had also proposed the practice of this mobility based on indirect evidence (e.g. the location of sites, locations of raw material sources, animal mortality profiles, and the absence of evidence for agriculture "in situ") (Geddes, 1983; Helmer, Gourichon, Maamar, \& Vigne, 2005; Lancelotti et al., 2014). These herd management strategies coexisted with other sedentary ones where mountain agriculture (at more than 1,000 m a.s.l.) was also practiced (Antolín et al., 2018).

The Early Neolithic occupations of the Cova Colomera are relevant to this discussion, is located in the pre-Pyrenean area at $670 \mathrm{~m}$ a.s.l., and in a natural and historical area through which the flocks passed.

The use of this cave by Neolithic shepherds is confirmed by the fumier deposit identified inside (Bergadà \& Oms, 2021). The French term fumier is used to designate sequences consisting of an accumulation of dung, burned and unburned, produced by the use of the caves as a sheepfold and subsequent burning to remove parasites (Angelucci, Boschian, Fontanals, Pedrotti, \& Vergès, 2009; Brochier, Villa, Giacomarra, \& Tagliacozzo, 1992). In the Cova Colomera, this dung accumulation is mainly due to domestic caprines (Bergadà \& Oms, 2021). In the Southern Pyrenees, other Early Neolithic and Middle Neolithic caves with fumier levels have been documented, e.g. Cova de Els Trocs, Chaves, and Coro Trasito (Clemente-Conte et al., 2016; Rojo et al., 2013; Utrilla \& Laborda, 2018).

The main objective of this work is to shed light on the beginning of husbandry in the Pyrenees through a zooarchaeological study of the Early Neolithic remains of the Cova Colomera, specifically, in relation to the composition and use of the herds and the exploitation of the region by these herds and shepherds.

\section{Geographical and Archaeological Context}

The Cova Colomera (Sant Esteve de la Sarga, Lleida) is situated in the Serra del Montsec (Figure 1), which is characterized by a rugged morphology, with a maximum altitude of $1,350 \mathrm{~m}$ a.s.l. This mountain range acts 
(a)

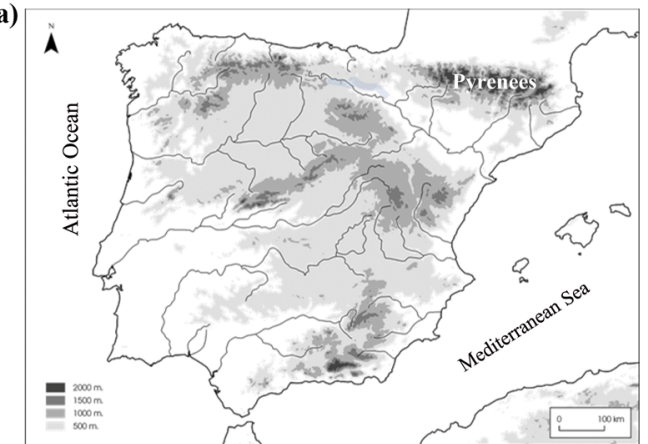

(b)

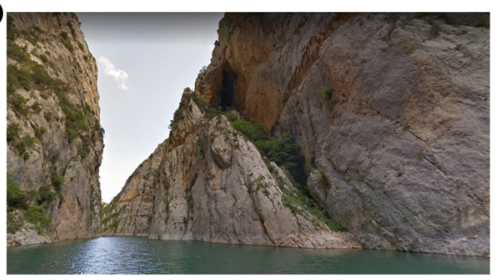

(e)

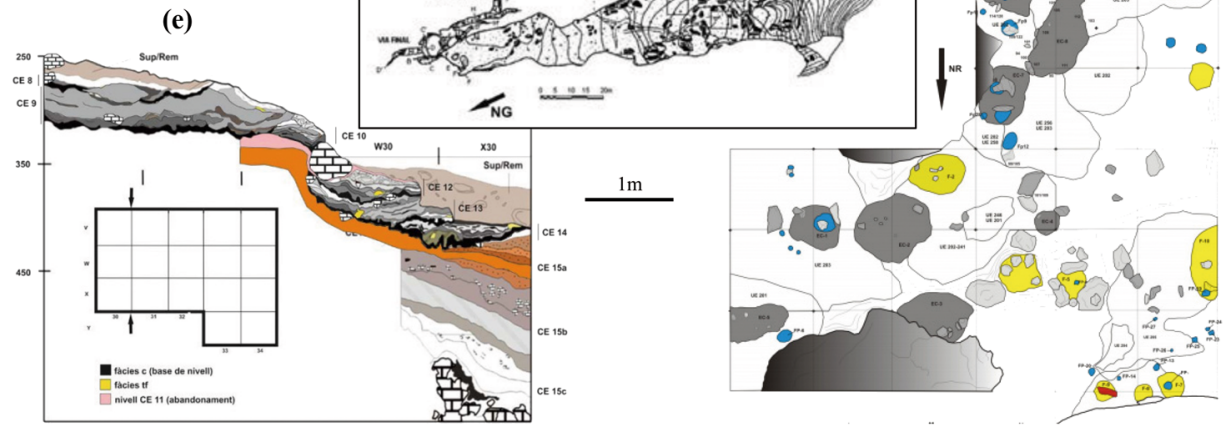

Figure 1: (a) Location of the Cova Colomera, (b) view of the cave from the river, (c) radiocarbon dates of Early Neolithic levels and stratigraphic units, (d) plan of the interior of the cave with the location of the two test pits, (e) stratigraphic section of sector CE, and $(f)$ stratigraphic section of sector CV.

as a biogeographical and bioclimatic barrier between the rainier and wetter northern area and a southern area with lower rainfall. A great quantity of pastures is available throughout the year due to the Mediterranean-type vegetation in the southern area and a sub-Mediterranean or Atlantic type to the north (Solà, 2003). Thus, this area was traditionally used for the grazing of herds and for transhumant movements (Miralles \& Tutusaus, 2005; Solà, 2003).

The Cova Colomera lies the northwestern foothills of the Montsec range, in the Mont-Rebei Gorge (Figure 1), at $670 \mathrm{~m}$ a.s.l. and $160 \mathrm{~m}$ above the River Noguera Ribagorzana. There has been a dam in this area since the 1920s. The cave has preserved one main entrance, which is $70 \mathrm{~m}$ high and $30 \mathrm{~m}$ wide (Oms et al., 2008, 2013); access to it is steep and difficult (Figure 1).

Systematic modern excavations began in 2005 and continued until 2011 (Oms et al., 2008, 2015). These works focused on two different areas of the cave. The first is a test pit of about $13 \mathrm{~m}^{2}$, which was excavated in the sheepfold area, located between the vestibule and the interior of the cave (henceforth CE, Oms et al., 2013). Here, six archaeological levels and a pit were documented. Three levels correspond to at least three occupations from the late Early Neolithic period (CE12-CE14) (Figure 1) (Oms et al., 2015).

The second excavation area covers an area of $26 \mathrm{~m}^{2}$, located in the cave hall (henceforth CV). In this area, dwelling structures (identified as stratigraphic units), dated to different periods from the Early Neolithic to the present, were documented. The Early Neolithic structures present a distinct typology: occupation levels, post-holes, pits, and hearths, although not all of them have faunal remains (Oms et al., 2015) (Figure 1). According to their spatial relationship, it was possible to distinguish at least two phases of occupation in the CV area (Oms et al., 2013). In the older one, there are two hearths (H1 and H8) 
and several post-holes; in the later phase, level II. The rest of the Early Neolithic structures could not be assigned to any phase due to the complexity of the spatial distribution and the overlap with structures from other periods.

The archaeological data do not suggest simultaneous occupation of the sheepfold and the habitat area. It has also been observed that the occupations in both areas had different durations. The older phase of CV and CE13 is attributed to shorter occupations than the second phase of CV and CE14 and CE12 (Oms et al., 2013).

From an archaeological point of view, the remains recovered in both areas comprise pottery, lithic artifacts, evidence of domestic plants (seeds and charcoals), and faunal remains. The morphology and decoration of the pottery are coherent with the radiocarbon dates (Figure 1) (Mangado, Morales, Oms, Rey, \& Sánchez de la Torre, 2012; Oms et al., 2013, 2015).

From a paleoenvironmental point of view, micromammal analysis indicates a temperate climate that can be identified by the presence of Mediterranean-thermophilic species (Bañuls-Cardona \& López-García, 2011, 2016; López-García et al., 2010). Yet, these studies also show the existence of a mixed environment, with the presence of forest-dwelling species together with open-air species. Temperatures were $2.4^{\circ} \mathrm{C}$ lower, and precipitation levels were higher than at present (Bañuls-Cardona \& López-García, 2016).

\section{Materials and Methods}

The faunal remains studied come from the Early Neolithic levels and structures of the Cova Colomera. That is, they come from CE12, CE13, and CE14 in the case of the fumier area. In the case of the CV area, the remains come from a variety of structures (Table 1).

The faunal sample of Cova Colomera was studied by taxonomic and anatomical identification. In the specific case of distinguishing between the sheep and goats, dental (Halstead, Collins, \& Isaakidou, 2002; Helmer, 2000; Payne, 1985) and postcranial morphological criteria were used (Boessneck, 1969; Prummel \& Frisch, 1986; Zeder \& Lapham, 2010).

Biometric data were used to differentiate the bovine remains, comparing the Cova Colomera measures with others available from different Neolithic and Bronze Age sites in the Iberian Peninsula (Altuna \& Mariezkurrena, 2001, 2007-2008; Barrachina \& Sanchis, 2008; Castaños, 1991, 1997, 2004; Riquelme, 1996).

Table 1: Distribution of the number of faunal remains (NR), the number of identified specimens (NISP), and the percentage of NISP (\%NISP) in relation to the total sample, by level and stratigraphic unit

\begin{tabular}{llrrr}
\hline & Levels/Structures & NR & NISP & \%NISP \\
\hline CE & CE12 & 396 & 146 & 36.9 \\
& CE13 & 85 & 24 & 28.2 \\
& CE14 & 409 & 82 & 20 \\
CV & Total & $\mathbf{8 9 0}$ & $\mathbf{2 5 2}$ & $\mathbf{2 8 . 3}$ \\
& H1 & 12 & 6 & 50 \\
& H8 & 10 & 2 & 20 \\
H9 & 118 & 13 & 11 \\
& P9 & 3 & 1 & 33.3 \\
& PH7 & 1 & 0 & 0 \\
PH8 & 2 & 0 & 0 \\
Total & PH12 & 1 & 1 & 100 \\
& Level II & 235 & 53 & 22.5 \\
& Total & $\mathbf{3 8 2}$ & $\mathbf{7 6}$ & $\mathbf{1 9 . 9}$ \\
& & $\mathbf{1 , 2 7 2}$ & $\mathbf{3 2 8}$ & $\mathbf{2 5 . 8}$ \\
\hline
\end{tabular}

Abbreviations: $\mathrm{H}$, hearth; $\mathrm{P}$, pit; $\mathrm{PH}$, post-hole. 
When taxonomic identification was not possible, the remains were classified by weight-size category (large size: $>300 \mathrm{~kg}$; medium size: $300-50 \mathrm{~kg}$; small size: $50-15 \mathrm{~kg}$; very small size: $<15 \mathrm{~kg}$ ). When identification of the skeletal elements was not possible, the remains were classified by general categories: long bone (appendicular) and flat bone (axial).

The results are presented in terms of the number of remains (NR) (which includes determined and undetermined specimens), the number of identified specimens (NISP), and the minimum number of individuals (MNI) as quantitative units. The minimum number of elements (MNE) and the standardized minimum animal unit (\%MAU) were also calculated in the case of the taxa that present the highest NISP (goat and sheep remains from CE and CV, and cattle remains from CE) (Binford, 1978; Lyman, 1994, 2008).

Given the high degree of breakage of the remains, the extent of fragmentation of the assemblage was also quantified by means of the \%whole (Lyman, 2008). To interpret the anatomical representation of the main taxa, density and standardized food utility indices (sFUI) (Binford, 1978; Ioannidou, 2003; Lyman, 1994; Metcalfe \& Jones, 1988) were compared with \%MAU through a correlation test (Spearman's rho). Since different parts of the same bone have different density and food utility indices, the correlation was made based on \%MAU by anatomic sections (Lyman, 1994).

Bone and dental criteria (Deniz \& Payne, 1982; Grant, 1982; Martín \& García-González, 2015; Noddle, 1974; Payne, 1973, 1987) were used for the estimation of the age at death of these animals.

The taphonomic analysis provided information on faunal consumption. All the remains were studied macroscopically and microscopically (magnification up to 110x), and anthropic marks such as cut marks, percussion marks (notches, flakes, etc.), bone breakage, and culinary alterations (boiling and burning) were identified (Binford, 1981; Lyman, 1994; Shipman \& Rose, 1983). Tooth marks were analyzed using morphological criteria (Brain, 1981; Fernández-Jalvo \& Andrews, 2011; Saladié, Rodríguez-Hidalgo, Díez, Martín-Rodríguez, \& Carbonell, 2013). Boiled bones were identified by macroscopic and microscopic criteria (Botella, Alemán, \& Jiménez, 2000; Bosch et al., 2011).

\section{Results}

A total of 1,272 remains were analyzed, most of which (70\%) were recovered in sector CE (Table 1). The distribution of faunal remains in the structures in sector CV is very varied. The highest NR in this area was recovered in level II, whereas in three structures only one item was recovered (Table 1).

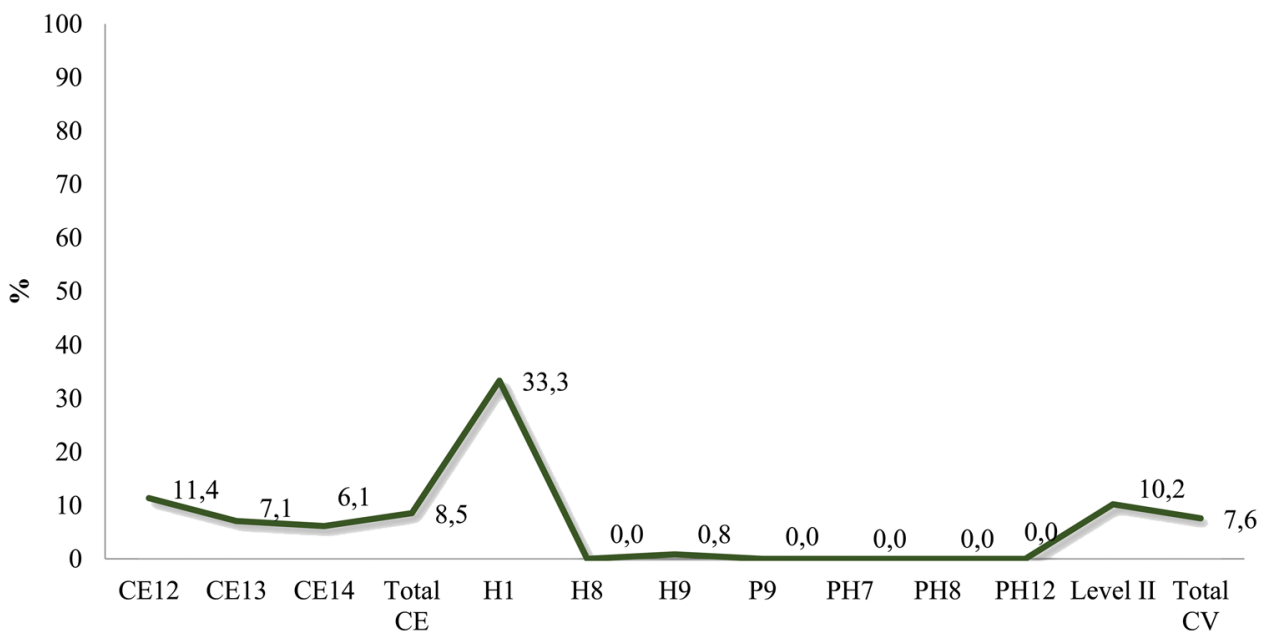

Figure 2: \%Whole values by levels or structures. 
The NISP also varies (Table 1) but in general it is low. This is as a result of the high level of fragmentation of remains in this type of assemblage, produced by human activities. Only in some structures in sector $\mathrm{CV}$, there is a high NISP, because the NR is generally low. In relation to this, each of the levels as well as the sum of the two sectors show very low \%whole values (Figure 2). In other words, the assemblage shows a low percentage of complete bones.

\subsection{Taxonomic Composition}

The two sectors present a similar taxonomic composition but in the CE levels greater taxonomic diversity was recorded (NTAXA = 9, in CE; NTAXA = 6, in CV), probably due to the higher number of remains (Table 2; Figure 3). Sheep and goats are the best-represented taxa, with $50 \%$ or more of the total NISP in both sectors. Mandible morphology and several postcranial features in a few cases allow the sheep and goats to be differentiated among the $\mathrm{CE}$ and $\mathrm{CV}$ domestic caprines (Table 2). The relative importance of caprines decreases if the MNI is under consideration, although they still show higher percentages than the other taxa (Figure 3).

The biometric data for bovines situate them within the range of variation of domestic individuals measured from other Neolithic and Bronze Age sites in the Iberian Peninsula (Table S1).

In some archaeological structures in sector $\mathrm{CV}$, cattle are the only taxon represented, but in general, their values, especially the NISP, are low (Table 2; Figure 3). Rabbits are present in both sectors and their MNI percentages are similar to those of domestic caprines in sector CV (Table 2; Figure 3). Suid (Sus sp.) remains are also present in both sectors, but it was not possible to establish whether their status was wild or domestic due to the lack of diagnostic anatomical features (such as third molars or the mandibular symphysis) and the impossibility of carrying out an osteometric study (Table 2; Figure 3). Other wild species play a secondary role in the assemblage composition (Table 2; Figure 3). The wild species are representative of the faunal spectrum of the area surrounding the Cova Colomera and provide evidence of hunting, e.g., roe deer (Capreolus capreolus), rabbits, and birds.

\subsection{Anatomical Composition}

The study of anatomical representation focused on the two main taxa: domestic caprines and cattle. Domestic caprines are mainly represented by elements of the appendicular skeleton, although some elements of the axial skeleton are also documented. The anatomical representation is more complete in sector CE because the NISP is higher than in the structures of sector CV (Figure 3; Table S2). Rabbits and cattle are also represented by a significant part of the skeleton, especially the appendicular. The anatomical representation of the other taxa is partial (Figure 4; Tables S3 and S4). The most complete anatomical representation is documented in levels CE12 and CE14. The representation in the structures of sector CV is very sporadic, and for this reason, the \%MAU of these elements was not calculated (Table S4). On all levels, the presence of the distal parts of the legs is remarkable. Taking into account the difficulty of taxonomic and anatomical identification entailed by the high degree of fragmentation of the assemblage, the \%MAU of the sheep and goats and the cattle is compared with that of the two corresponding weight sizes (Figures 4 and 5). Both weight sizes show high values of \%MAU for the axial skeletal elements. These may be overestimated due to the low NISP of these elements and the fact that some of them, such as skull and vertebrae, are not divided by sections. These elements could complement the anatomical representation of sheep and goats, as the elements of the axial skeleton are difficult to identify due to the high degree of fragmentation. In the case of cattle, the predominance of the distal ends of the legs is complemented by the presence of these large-sized elements of the axial skeleton. 


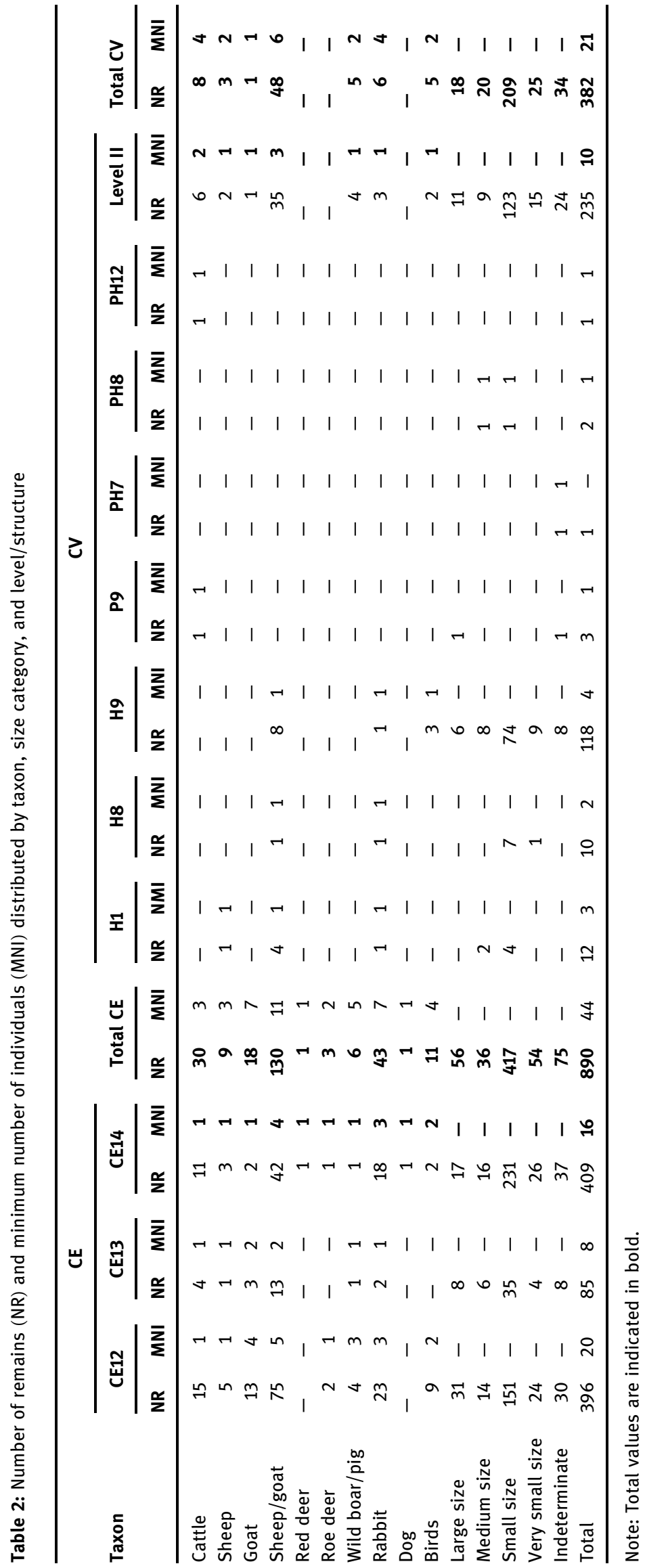


Table 3: Spearman's rho correlation of \%MAU and the density and utility indices of the levels and structures of CE and CV that present more than 10 sheep/goats or cattle remains

\begin{tabular}{|c|c|c|c|c|}
\hline & \multicolumn{2}{|c|}{ Sheep } & \multicolumn{2}{|c|}{ Cattle } \\
\hline & Density & Utility & Density & Utility \\
\hline \multirow[t]{2}{*}{ CE12 } & $r^{2}=0.26712$ & $r^{2}=-0.27946$ & $r^{2}=0.31519$ & $r^{2}=0.55002$ \\
\hline & $p=0.095664$ & $p=0.20783$ & $p=0.29419$ & $p=0.44444$ \\
\hline \multirow[t]{2}{*}{ CE13 } & $r^{2}=0.32791$ & $r^{2}=0.093694$ & $r^{2}=-0.31623$ & $r^{2}=0.44721$ \\
\hline & $p=0.2328$ & $p=0.75004$ & $p=0.6$ & $p=0.66667$ \\
\hline \multirow[t]{2}{*}{ CE14 } & $r^{2}=0.025911$ & $r^{2}=0.3015$ & $r^{2}=0.42586$ & $r^{2}=0.51972$ \\
\hline & $p=0.88618$ & $p=0.17269$ & $p=0.11349$ & $p=0.25$ \\
\hline \multirow[t]{2}{*}{ II } & $r^{2}=0.14649$ & $r^{2}=0.51524$ & - & - \\
\hline & $p=0.53771$ & $p=0.049345$ & & \\
\hline
\end{tabular}

\%NISP CE

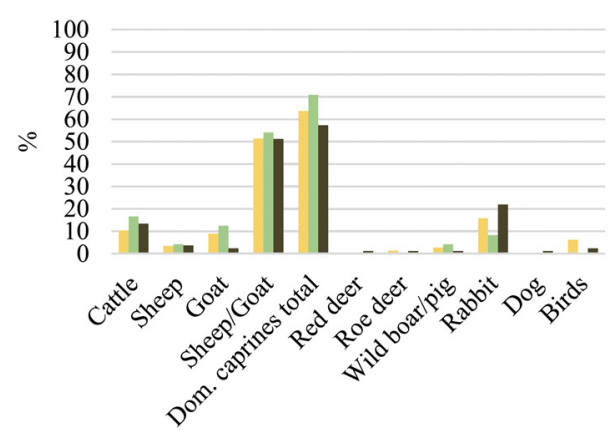

\%NISP CV

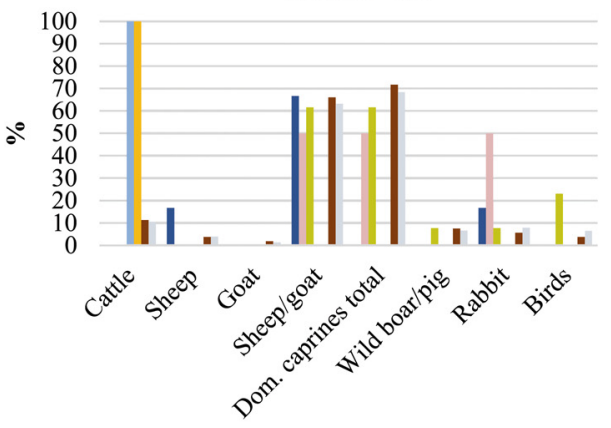

\%MNI CE

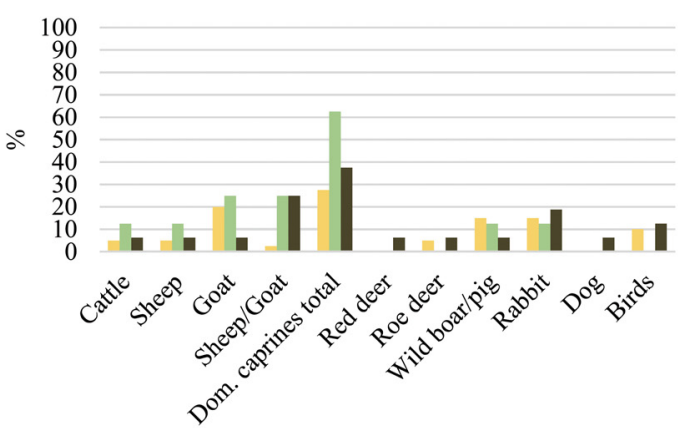

$\%$ MNI CV

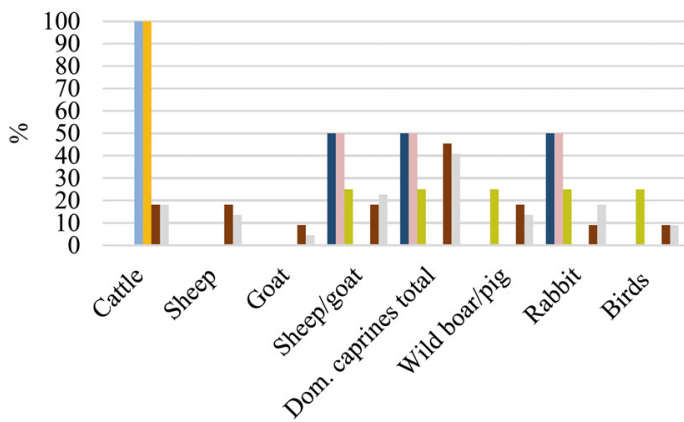

Figure 3: \%NISP and \%MNI of each taxa, calculated with respect to the total NISP and the total MNI, from the levels or structures in the CE and CV areas.

The results of the Spearman rho indicate that the partial nature of the anatomical representation cannot be attributed to conservation issues related to the differential density of the remains since there is no correlation between the \%MAU and the density indices (Table 3). The Spearman rho $p$ values indicate that there is a significant positive correlation between the \%MAU and the food utility indices only in the case of the level II domestic goat carcasses from sector CV (Table 3).

\subsection{Age at Death}

The age at death of the domestic caprines and cattle was calculated. Bone and tooth criteria were used for age determination because the tooth sample is small. The extended data are presented in the Supplementary 


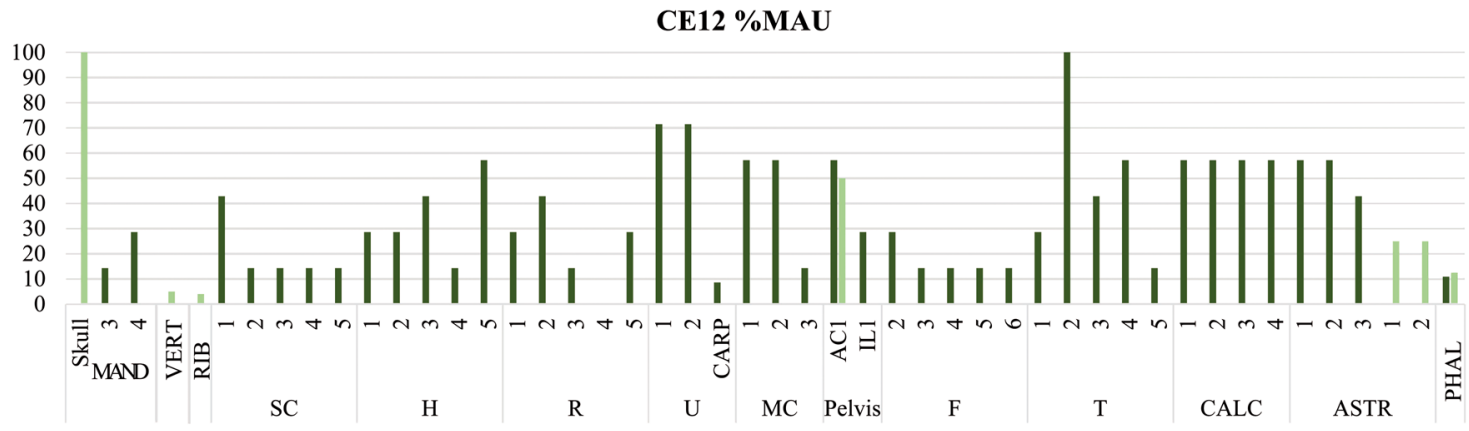

CE13 \%MAU

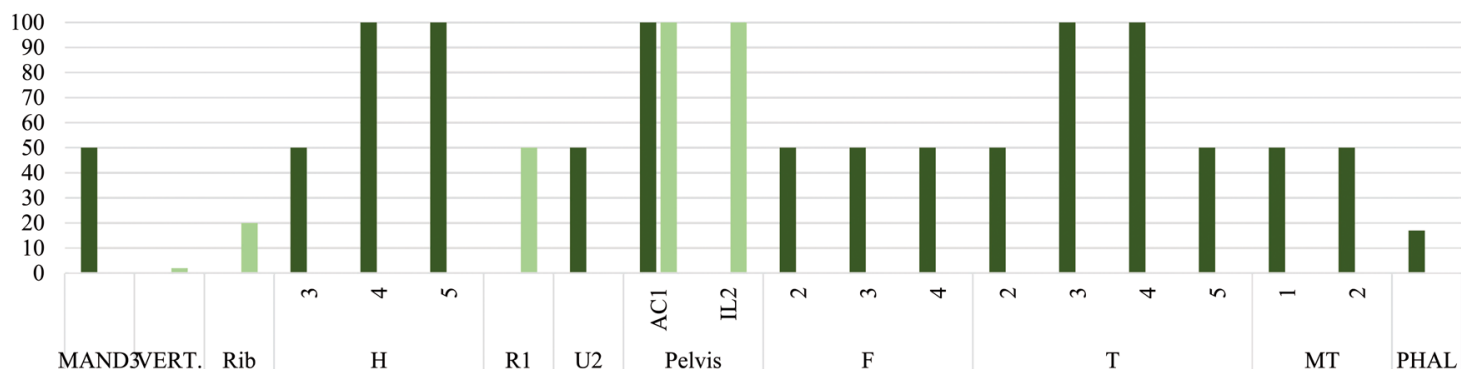

CE14 \%MAU

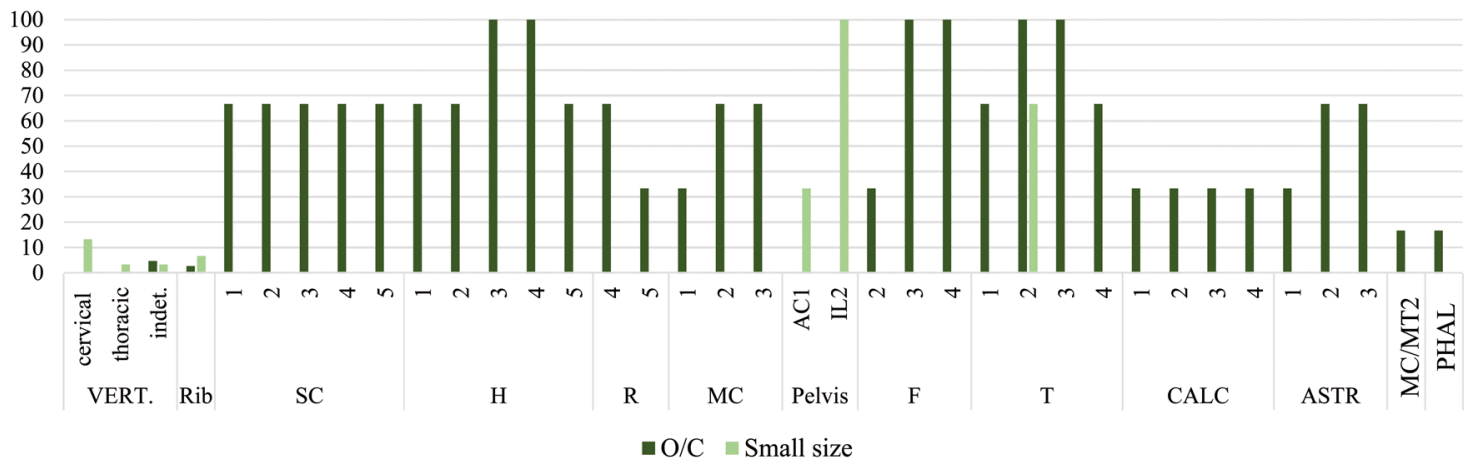

Level II

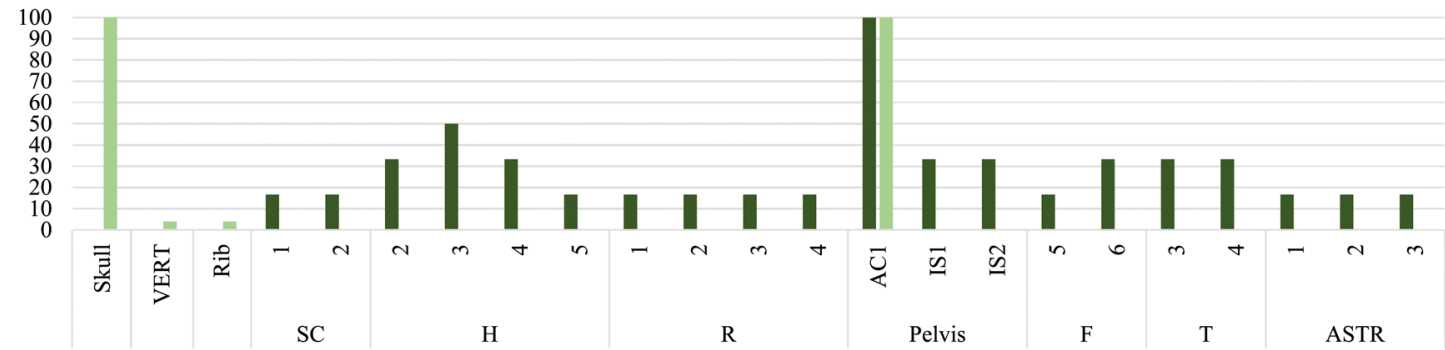

Figure 4: Graphic representation of the \%MAU of sheep and goats of all levels with more than 10 remains.

Material $^{1}$ (Tables S5 and S6), specifying the criteria for determining age in each case, and the data for sheep are summarized in Figure 6. Both immature and adult domestic caprines were documented in sector CV and CE12 and CE14. In CE13, no adult individuals were identified. Among immature individuals, the presence of fetuses and neonates stands out. One fetal individual was documented in CE14, one neonatal individual in CE12, and two perinatal (fetus/neonate) individuals in CE12 and II, respectively.

1 See supplementary tables at https://doi.org/10.1515/opar-2020-0190. 
CE12 \%MAU
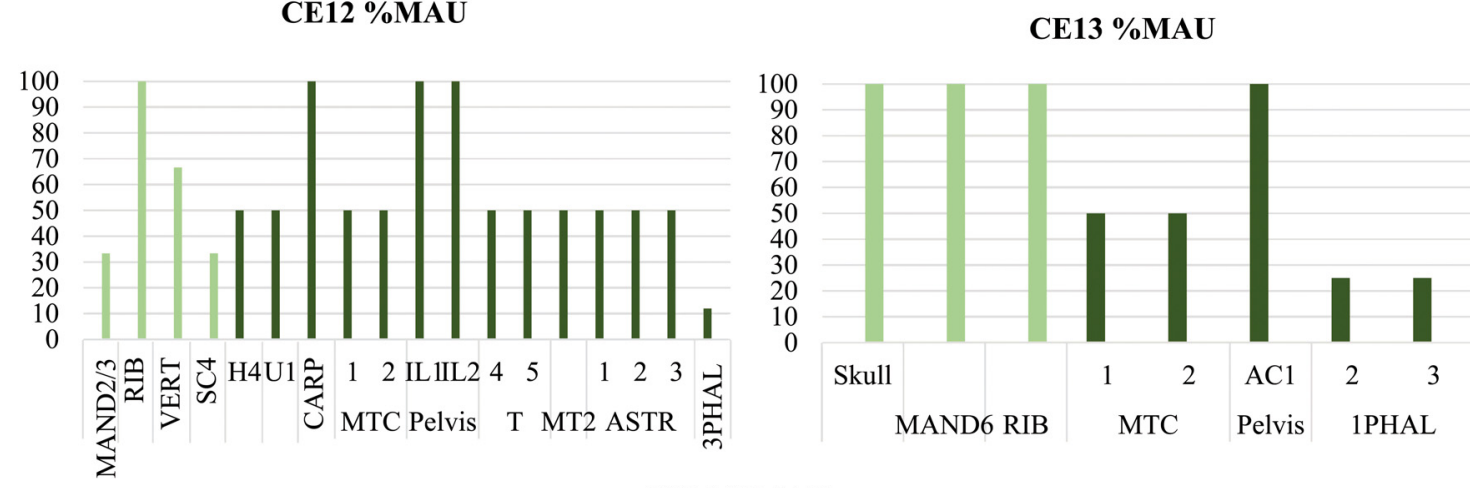

CE14 \%MAU

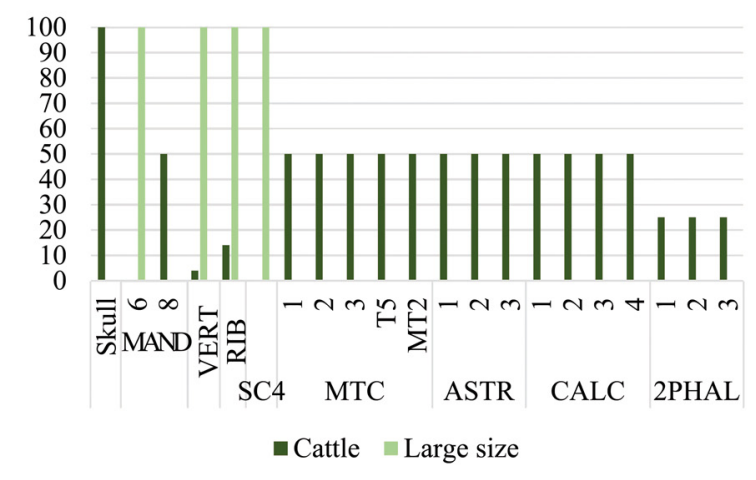

Figure 5: Graphic representation of the \%MAU of cattle of all levels with more than 10 remains.

The cattle age-at-death data are more limited because of their low NISP and MNI (Tables S5 and S6), and in most cases, it is not possible to establish precise ranges of age at death. In CE12 and level II, at least two individuals were identified: one immature and one juvenile and/or adult.

\subsection{Faunal Processing}

Both domestic and wild species present butchering marks (Figure 7; Table S7). All taxa show evidence of anthropogenic processing, except for the red deer, which is represented only by an unfused distal epiphysis. As mentioned earlier, breakage affected a major part of the assemblage.

Cut marks in the sheep/goat remains provide information on the occurrence of all the butchering phases: skinning, dismembering, disarticulation, evisceration, and defleshing (NR = 108). Most cut marks were concentrated in sheep/goat and small-sized remains, and all the butchering phases were documented (Figure 7).

Cattle, roe deer, rabbits, and dogs also present cut and/or percussion marks. Cattle were defleshed in CE13, disarticulated in CE12, skinned and eviscerated in CE14, and disarticulated and defleshed in level II. The cut marks in the roe deer tibia are indicative of animal defleshing, whereas the rabbits were disarticulated and defleshed.

Evidence of culinary processing is also documented, affecting remains from most taxa and weight-size categories. Bearing in mind the dung burning in sector CE, the burnt bones could be related both to this process and to the cooking of the carcasses. The documentation of processing marks on the CE14 dog remains is notable. The location of the incisions, on the posterior side of the radius diaphysis, is an indication of the defleshing of the dog.

Tooth marks are present on 256 remains $(\% \mathrm{NR}=20.1 \%)$. Taking into account the presence of some shallow scores with internal microstriations on the walls and bottoms of some grooves $(\mathrm{NR}=7)$, these could be linked with human tooth marks. 

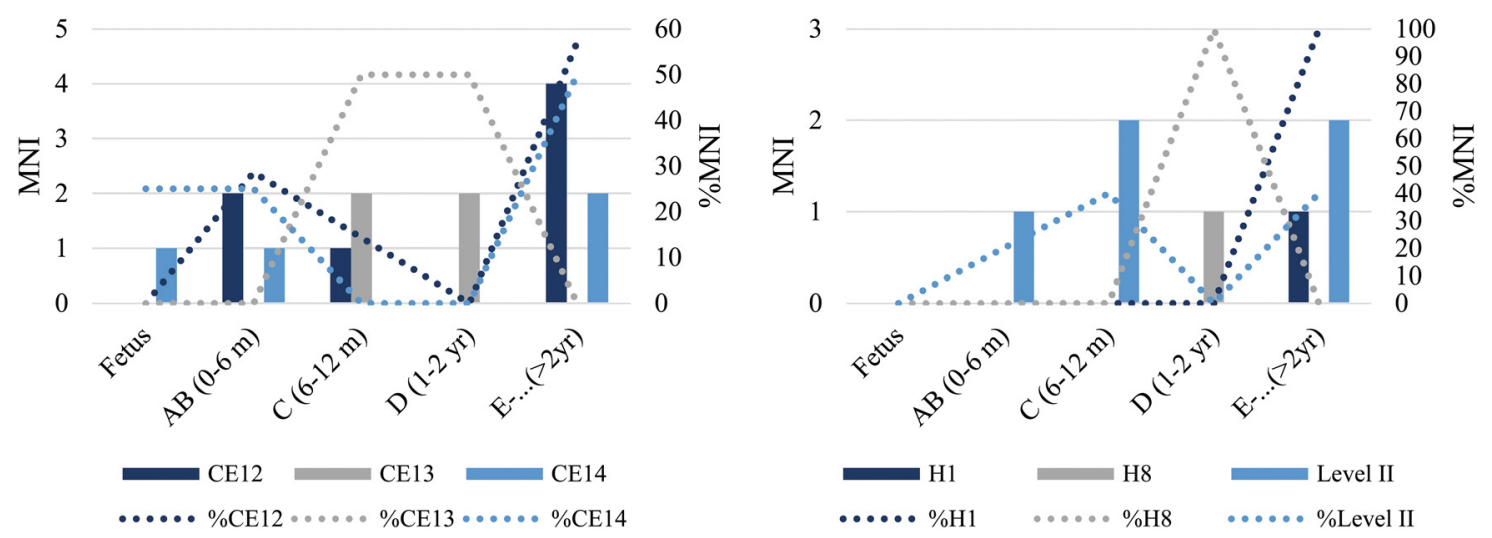

Figure 6: Mortality profiles of domestic caprines recovered in sectors CE and CV. The classification is based on the age categories of Payne (1973).

Manganese dioxide was the main inorganic taphonomic agent documented in the assemblage, specifically in $35 \%$ of the remains.

\section{Discussion}

\subsection{Cova Colomera Flocks: Composition and Use}

The taxonomic composition documented in the Cova Colomera confirms its occupation by shepherds during the Early Neolithic period. According to the presence of the fumier deposit in sector CE (Bergadà \& Oms, 2021), the fauna is dominated by mixed herds of domestic sheep and goats. The predominant breeding of these two species is one of the characteristics of most of the sheepfold caves (e.g. Blaise, 2005; Bréhard, Beeching, \& Vigne, 2010; Castaños, 2004; Helmer et al., 2005; Miracle, 2006; Mlekuž, 2006; Nicod et al., 2008; Pérez-Ripoll, 2006; Vigne, 2007) and in general of most Early Neolithic sites in northeast Iberia (Antolín et al., 2018; Saña et al., 2020).

Age-at-death profiles throw light on the sheep and goat use in the Cova Colomera. The presence of immature individuals less than 12 months old and adults older than 2 years indicates the use of meat and milk (Payne, 1973). The death of neonatal and fetal individuals may be due to intentional sacrifice or nondeliberate causes. Between $2 \%$ and $5 \%$ of perinatal deaths in the current herds of the Iberian Peninsula are caused by non-deliberate causes (Cambero, 1997). The intentional sacrifice of these individuals can cause difficulties in surviving in household economies. Therefore, we consider that the death of the perinatal individuals of the Cova Colomera is best attributed to non-deliberate causes, as has already been proposed in other sheepfold caves (Boschin, 2020; Martín, García-González, Nadal, \& Vergès, 2016). The sacrifice of adult individuals could also be associated with meat production as well as with herd maintenance strategies, for example, the sacrifice of unproductive ewes. These kill-off patterns are similar to those observed in the other two sites in the Pyrenean area for which this type of data is available, that is Chaves, Els Trocs cave, and Espluga de la Puyascada (Castaños, 1987; Sierra et al., 2019; Tejedor-Rodríguez et al., 2021).

In addition to the proteins provided by sheep and goats, the shepherds of the Cova Colomera also obtained meat from cattle, wild boar/pigs, and several species of wild animals, especially rabbits. In addition to the contribution of meat, these animals could be a source of secondary products such as skins. This type of exploitation is widely documented among the current shepherds of the Pyrenees and in many of the Early Neolithic caves in this region (e.g. Castaños, 1987; Castaños, 2004; Clemente-Conte et al., 2016; Rojo et al., 2013). 

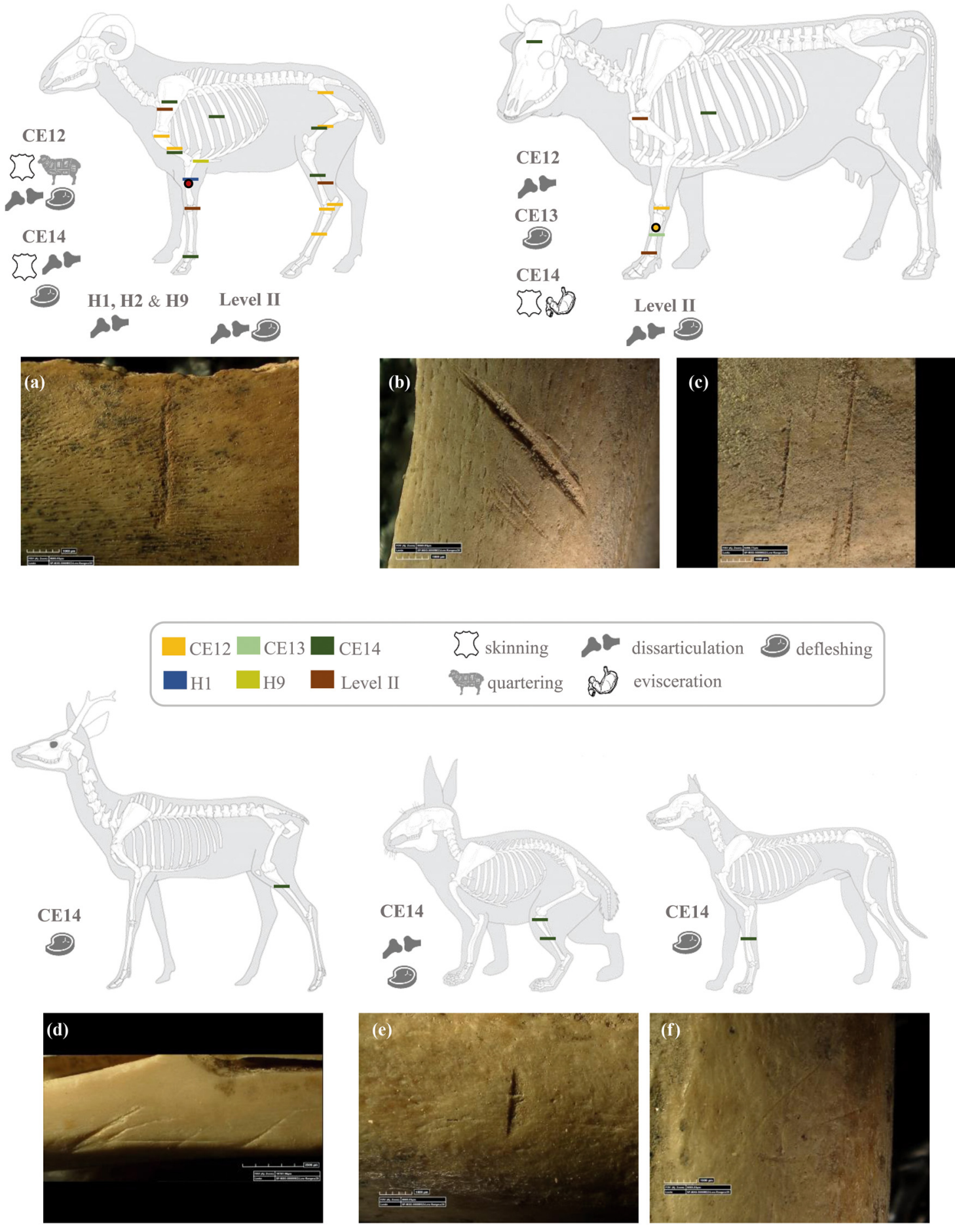

Figure 7: Location of cut marks (line) and percussion marks (circle) by anatomical element and taxon. Detail photographs (Hirox KH8700 digital microscope) of some of these cut marks, all of them indicating the defleshing of the animals: (a) incision in scapula of domestic caprine (CE14), (b and c) incisions in cattle metacarpus (CE13), (d) incisions in rabbit tibia (CE14), and (e and $\mathrm{f}$ ) incisions in dog radius (CE14).

Occasionally, the dog was also a source of meat for the shepherds of the Cova Colomera. The consumption of domestic dogs in particular, and small carnivores in general, was not common during the Neolithic period. However, a variety of evidence for this has been documented in the Neolithic occupations of the 
Iberian Peninsula, some from other sheepfold caves (Alférez, Molero, Bustos, \& Brea, 1981; García-Moncó, 2008; Llorente, 2015; Martín, Saladié, Nadal, \& Vergès, 2014; Sanchís \& Sarrión, 2004). These cases are probably associated with one-off consumption episodes seeking to maximize the use of available resources.

\subsection{The Use of the Natural Resources of the Pyrenean Region by Herders}

As mentioned earlier, Pyrenees has been a traditional location of husbandry practices and herd movements, ranging from small to large scale (over $100 \mathrm{~km}$ ) (Miralles \& Tutusaus, 2005). The current state of the question indicates that, during the Early Neolithic, a mixed occupation model was developed in the Pyrenees, with settlements of long and short duration (Antolín et al., 2018).

In this context, the Colomera Cave could be included in the group of sites with short-term/less intensive occupations. The faunal sample of the Cova Colomera is not abundant in any of the sectors studied and is especially scarce in the CV habitat area. The statistical and taphonomic analyses carried out on the sample indicate that its size is not conditioned by various factors that sometimes affect this type of assemblage. There is no statistical correlation between the density of the different anatomical sections and their conservation. The presence of the remains of fetal and neonatal individuals, which show lower bone-density indices (Ioannidou, 2003), can also be taken as evidence of the good conservation of the assemblage. In addition, the incidence of humans as a taphonomic agent is higher than that of carnivores or other postdepositional agents.

Other factors that can condition the sample size of an archaeological site relate to decisions made during the excavation work. In the case of test pits, as at the Cova Colomera, the main factor is the extension of the excavation area. For this reason, the correlation of the volume of sediment excavated with the number of recovered remains was evaluated using Spearman's rank-order correlation coefficient. There was found to be no correlation between the number of remains recovered and the volume of sediment excavated $\left(r^{2}=0.5 ; p=1\right)$. Therefore, the size of the sample from the Cova Colomera is directly related to the human activity undertaken during the Early Neolithic occupations. As proposed in previous works (Oms et al., 2013) on the archaeological material of the cave, we consider that the low number of faunal remains is directly linked to the duration and/or intensity of Early Neolithic occupations. In addition, micromorphological studies observe a high degree of preservation of the fumier, which could correspond to the small herd size (Bergadà \& Oms, 2021). Also in accordance with these studies (Oms et al., 2013) are the differences observed in the intensity and/or duration of these occupations, as shown by faunal analyses. Level CE13 and the first phase of occupation of the $\mathrm{CV}$ area (H1 and H8) appear to be of shorter duration and/or less intense than levels CE14 and CE12 and the second phase of the occupation of CV (level II). Shorter and/or less intensive occupations would be associated with less waste generation and therefore with the recovery of fewer archaeological remains.

Seasonal or short-term occupation has also been proposed for other Early Neolithic caves in the Pyrenean area with evidence of husbandry practices, such as Sardo (1,790 m a.s.l.) (Gassiot et al., 2015), Els Trocs (1,530 m a.s.l.) (Rojo et al., 2013), and Coro Trasito (1,548 m a.s.l.) (Clemente-Conte et al., 2016). The seasonal occupation was also proposed for the Espluga de la Puyascada (1,300 m a.s.l.) (Rodanés \& Ramón, 1995; Utrilla \& Baldellou, 1996), although recent studies propose continuous occupation (Sierra et al., 2019). The proposal of seasonal occupation for these caves is based on varying criteria (Rojo et al., 2013), such as micromorphological features and the origin of raw materials (Mazzucco, Clemente-Conte, \& Gassiot, 2019). In Els Trocs cave, a zooarchaeological approach, by means mortality profiles and isotopic values $\left(\delta^{18} \mathrm{O}\right)$ of sheep, was used. These data inform about the occupation of the cave during the summer (Tejedor-Rodríguez et al., 2021).

In the case of the Cova Colomera, the scarcity of determinable remains also conditions the information available on mortality profiles. In the area of habitat, the scarce information available precludes even an approximate assessment of the season in which these occupations took place. The main information comes from the mortality profiles of the ovicaprines recovered in the sheepfold area. The mortality peaks indicate 
their presence in the cave at certain times of the year. Although autumnal lambing was documented (Sierra et al., 2021; Tejedor-Rodríguez et al., 2021; Tornero et al., 2020), the natural and most common birthing season for Early Neolithic sheep and goats is spring (e.g., Balasse et al., 2017; Cassinello, 2017; Hafez, 1952; Santiago-Moreno, López-Sebastián, González-Bulnes, Gómez-Brunet, \& Chemineau, 2000; Tornero et al., 2020). Given this data, the occupation of CE13 would have at least been in autumn, that of CE14 at least in late winter and spring, and that of CE12 in spring and autumn. In any case, the cave was occupied at different times of the year, and no pattern of seasonality is observed in each specific occupation.

The short duration and/or low intensity of the fold occupations in the Cova Colomera has also been observed through the study of other materials (Oms et al., 2013), which indeed establish a shorter occupation in level CE14 and in the first phase of the CV area. In these levels and structures, a smaller volume of archaeological material is observed, and fewer faunal remains. In line with the brevity and/or the low intensity of the occupation, the paleoenvironmental data indicate that the degree of the anthropization of the environment is low, with a predominance of wooded vegetation, even in the Bronze Age (BañulsCardona \& López-García, 2016).

In light of all these data together with those provided by the mortality profiles of the sheep and goats, the short duration of the occupations of the Cova Colomera could be related to two different livestock practices. (1) The shepherds who occupied the cave moved with small herds, covering short-to-medium distances. This would be in accordance with the information provided by the study of the sources of raw materials. The flint used by the shepherds of the Cova Colomera came from the close vicinity $(10-30 \mathrm{~km}$ away), although to a lesser extent flint was also supplied from the Ebro Valley (Mangado et al., 2012). (2) The flocks of the Cova Colomera were integrated into a system of wider, long-distance movements. Due to its intermediate location between the valley and the high peaks of the Pyrenees, the cave would thus have been used as a stopping point in spring and autumn. A weak point of this interpretation is the presence of fetal and neonatal individuals in levels CE12 and CE14, as these individuals are not usually included in long-distance movements.

\subsection{The Use of Cova Colomera by Herders}

The faunal remains of the Cova Colomera are highly affected by breakage, as are other archaeological remains such as pottery (Mangado et al., 2012). This makes it difficult to analyze the faunal remains but nevertheless provides information on human and herd activity within the cave. Given the fresh fracturing of a large part of the remains and the fact that statistical and taphonomic analyses point to humans as the main modifying agent of the assemblage, the high degree of breakage could be attributed to the anthropic manipulation of the remains.

The anatomical representation of domestic caprines is very complete. The elements of the axial skeleton are underrepresented, which is normal in this type of assemblage due to the lack of diagnostic traits to help identify them at a taxonomic level. However, they are represented in the group of small animals, corresponding to sheep and goats. On the other hand, alterations of anthropic origin shed light on the anthropic processing of these animals, as well as their use in cooking. The remaining taxa, except the red deer, present at least one alteration associated with human butchering. Rabbits are represented by a significant part of the skeleton, most probably because they were transported and processed entirely in the cave. The case of cattle is unusual, although their anatomical representation is partial even when the large-sized remains are also taken into consideration. The presence of the distal part of the limbs stands out, although the thorax and the skull are also represented; the latter represented above all by isolated teeth. It is possible that these animals were not bred as live animals in the cave but were brought inside as food pieces by the shepherds. Often, herders moving with their livestock are accompanied by fresh or cured meat (e.g. ham) and fat for feeding (Leizaola, 2008; Miralles \& Tutusaus, 2005). However, there is no correlation between the elements represented and their nutritional value. It is possible that the legs were transported completely and, once consumed, the long bone fragments were fractured to be boiled, discarding the distal elements of 
the legs. These could have become part of the group of large, long bones by losing their diagnostic anatomical features when fractured. This would be consistent with the fact that live cattle might have had some difficulty accessing the cave given the steepness of the terrain.

As far as the rest of the species are concerned, the anatomical representation is also very limited. The anatomical elements identified do not present a high index of alimentary utility. Like the cattle, they could have been fresh or dried meat transported by the shepherds.

As mentioned earlier, two different areas are documented in the Cova Colomera: a sheepfold area and a habitat area. In previous works, it has been proposed that the occupation of these two areas would not have been simultaneous, since it has not been possible to refit ceramic fragments from the two areas (Oms et al., 2013). Like the other archaeological material, the faunal remains do not allow a possible relationship of synchrony to be established in the use of the two areas. The identification of alterations associated with the butchering and cooking of remains from both areas indicates the practice of domestic activities in the cave, in accordance with the presence of the combustion and storage structures documented in sector CV.

The combined use of a cave as a habitat and a sheepfold area (whether simultaneous or not) has been documented in other Early Neolithic caves in the Pyrenean area, e.g. in Chaves and the Cova Gran de Santa Linya (Mora, Benito-Calvo, Martínez-Moreno, González, \& De la Torre, 2011; Oms et al., 2013; Utrilla \& Laborda, 2018).

\section{Conclusion}

The Early Neolithic occupations of the Cova Colomera are directly related to the activities of the first Pyrenean shepherds.

Husbandry in the Cova Colomera was based on the breeding of sheep and goats, which were exploited for their meat and milk. The presence of these animals in the cave is confirmed by the presence of their bone and dental remains and by the sheepfold area with its fumier deposits. Cattle would also have been bred by these communities but probably not moved into the cave with the herds of domestic caprines. The Cova Colomera was occupied at different times during the Early Neolithic period. The occupations were short and/or of low intensity and took place at different times of the year. The seasonality of the occupations could be associated with the practice of flock movements both on a short and long scale, already documented from the beginning of the Early Neolithic in other sites in the region. These data also illustrate the diversity in the use of caves by the first shepherds who inhabited the Pyrenees, with some caves undergoing a long occupation, such as Chaves, and others used temporarily, such as the Cova Colomera. The diversity in their use is related to the husbandry practices in the area from the very Early Neolithic.

Acknowledgments: We wish to acknowledge all archaeologists who have undertaken the fieldwork at the Cova Colomera.

Funding information: Financial support was received from research projects HAR2017-86509, SGR201700011, and PGC2018-093925-B-C32. P.M. was supported by a postdoctoral grant from the Juan de la Cierva Subprogramme (FJCI-2016-29045).

Conflict of interest: The authors state no conflict of interest.

\section{References}

Alcalde, G., Bosch, A., \& Buxó R. (1991). L’assentament neolític a l'aire lliure de Plansallosa (La Garrotxa). Cypsela, IX, 49-63. Alférez, F., Molero, F., Bustos, V., \& Brea, P. (1981). La Fauna de macromamíferos. Trabajos de Prehistoria, 38, 139-145. 
Altuna, J., \& Mariezkurrena, K. (2001). La cabaña ganadera del yacimiento de La Renke (Álava, País Vasco). Munibe, 53, 75-86. Altuna, J., \& Mariezkurrena, K. (2007-2008). Restos de alimentación de origen animal de los pobladores de la cueva de Arenza I (País Vasco) durante la Edad del Bronce. Veleia, 24-25, 843-877.

Angelucci, D. E., Boschian G., Fontanals, M., Pedrotti, A., \& Vergès, J. M. (2009). Shepherds and karst: The use of caves and rock-shelters in the Mediterranean region during the Neolithic. World Archaeology, 41(2), 191-214. doi: 10.1080/ 00438240902843659.

Antolín, F., Navarrete, V., Saña, M., Viñerta, A., \& Gassiot, E. (2018). Herders in the mountains and farmers in the plains? A comparative evaluation of the archaeobiologial record from Neolithic sites in the eastern Iberian Pyrenees and the southern lower lands. Quaternary International, 484, 75-93. doi: 10.1016/j.quaint.2017.05.056.

Balasse, M., Tresset, A., Bălăşescu, A., Blaise, E., Tornero, C., Gandois, H., ... Ivanova, M. (2017). Animal Board Invited Review: Sheep birth distribution in past herds: A review for prehistoric Europe (6th to 3rd millennia BC). Animal, 11(12), 2229-2236. doi: 10.1017/S1751731117001045.

Bañuls-Cardona, S., \& López-García, J. M. (2011). Análisis de los cambios paleoambientales del Pleistoceno superior finalHoloceno a partir del estudio de micromamíferos en la Cova Colomera (Sant Esteve de la Sarga, Lleida). In OrjÍA (Ed.), Actas de las II Jornadas de Jóvenes en Investigación Arqueológica. Tomo II (pp. 475-478). Zaragoza: Ediciones Pórtico.

Bañuls-Cardona, S., \& López-García, J. M. (2016). Climatic and environmental conditions from the Neolithic to the Bronze Age (7000-3000 BP) in the Iberian Peninsula assessed using small-mammal assemblages. Comptes Rendus Palevol, 15(8), 958-967. doi: 10.1016/j.crpv.2016.04.012.

Barrachina, A., \& Sanchis, A. (2008). Valoración diacrónica de un modelo económico de la edad del bronce: La fauna del poblado del Pic dels Corbs, Sagunt (València). Quaderns de Prehistòria de Castelló, 26, 43-94.

Bergadà, M. M., \& Oms, F. X. (2021). Pastoral Practices, Bedding and Fodder During the Early Neolithic Through Micromorphology at Cova Colomera (Southeastern Pre-Pyrenees, Iberia). Open Archaeology, 7(1), 1258-1273. doi: 10.1515/opar2020-0183.

Binford, L. R. (1978). Nunamiut ethnoarchaeolgoy. New York: Academic Press.

Binford, L. R. (1981). Bones: Ancient men and modern myths. Orlando: Academic Press.

Blaise, E. (2005). L'élevage au Néolithique final dans le sud-est de la France: Éléments de réflexion sur la gestion des troupeaux. Anthropozoologica, 40(1), 195-216.

Boessneck, J. (1969). Osteological differences between sheep (Ovis aries Linné) and goat (Capra hircus Linné). In D. Brothwell \& E. S. Higgs (Eds.), Science in archaeology (pp. 331-358). Londres: Thames and Hudson.

Boschin, F. (2020). Caprine mortality profiles from prehistoric cave-sites of the northern Adriatic: Livestock strategies or natural death? International Journal of Osteoarchaeology, 30(1), 3-12. doi: 10.1002/oa.2824.

Bosch, P., Alemán, I., Moreno-Castilla, C., \& Botella, M. (2011). Boiled versus unboiled: a study on Neolithic and contemporary human bones. Journal of Archaeological Science, 38(1), 2561-2570.

Botella, M. C., Alemán, I., \& Jiménez, S. A. (2000). Los huesos humanos. Manipulación y alteraciones. Barcelona: Bellaterra.

Brain, C. K. (1981). The hunters or the hunted? An INTRODUCTION TO African cave taphonomy. Chicago and London: The University of Chicago Press.

Bréhard, S., Beeching, A., \& Vigne, J.-D. (2010). Shepherds, cowherds and site function on middle Neolithic sites of the Rhône valley: An archaeozoological approach to the organization of territories and societies. Journal of Anthropological Archaeology, 29, 179-188. doi: 10.1016/j.jaa.2010.02.001.

Brochier, J. E., Villa, P., Giacomarra, M., \& Tagliacozzo, A. (1992). Shepherds and sediments: Geo-ethnoarchaeology of pastoral sites. Journal of Anthropological Archaeology, 11(1), 47-102. doi: 10.1016/0278-4165(92)90010-9.

Cambero, P. (1997). Cuaderno de la explotación de ovino. Salamanca: Servicio Agrario de Caja Duero.

Cassinello, J. (2017). Muflón-Ovis orientalis. In A. Salvador \& I. Barja (Eds.), Enciclopedia Virtual de los Vertebrados Españoles. Madrid: Museo Nacional de Ciencias Naturales.

Castaños, P. (1987). Estudio de los restos óseos de la cueva de Espluga de la Puyascada (Huesca). Bolskan, 4, 43-56.

Castaños, P. (1991). Estudio de los restos faunísticos de la Cueva del Moro (Olvena-Huesca). Bolskan, 10, 9-30.

Castaños, P. (1997). Estudio de la Fauna del Cerro I de "Los Castillejos" (Fuente de Cantos, Badajoz). Norba, 14, 11-45.

Castaños, P. (2004). Estudio arqueozoológico de los macromamíferos del Neolítico de la Cueva de Chaves (Huesca). Saldvie, 4, 125-171.

Clemente-Conte, I., Gassiot, E., Rey, J., Antolín, F., Obea, L., Viñerta, A., \& Saña, M. (2016). La cueva de Coro Trasito (Tella-Sin, Huesca): Un asentamiento pastoril en el Pirineo Central con ocupaciones del Neolítico antiguo y del Bronce Medio. In J. I. Lorente \& J. M. Rodanés (Eds.), I congreso de arqueología del patrimonio aragonés (pp. 71-80). Zaragoza: Colegio Oficial de Doctores y Licenciados en Filosofía y Letras y en Ciencias de Aragón.

Cortés, M., Jiménez, F., Simón, M. D., Gibaja, J. F., Faustino, A., Martínez-Ruiz, F., ... Bicho, N. F. (2012). The Mesolithic-Neolithic transition in southern Iberia. Quaternary Research, 77, 221-234. doi: 10.1016/j.yqres.2011.12.003.

Deniz, E., \& Payne, S. (1982). Eruption and wear in the mandibular dentition as a guide to ageing Turkish Angora goats. In B. Wilson, C. Grigson, \& S. Payne (Eds.), Ageing and sexing animal bones from archaeological sites (pp. 155-207). 0xford: BAR British Series 109. 
Esquembre, M. A., boronat, J. D., Jover, F. J., Molina, F. J., Luján, A., Fernández, J., ... Ortega, J. R. (2008). El yacimiento neolítico del Barranquet de Oliva (Valencia). In M. S. Hernánez, J. A. Soler, \& J. A. López (Eds.), Actas del IV congreso del neolítico peninsular (pp. 183-190). Alicante: Museo Arqueológico de Alicante.

Fernández-Jalvo, Y., \& Andrews, P. (2011). When humans chew bones. Journal of Human Evolution, 60, 117-123. doi: 10.1016/ j.jhevol.2010.08.003.

García-Moncó, C. (2008). De Brennan a Bogart. Un mayor papel protagonista para el perro entre las primeras sociedades productoras de la Península Ibérica. In M. S. Hernández, J. A. Soler, \& J. A. López (Eds.), IV congreso del neolítico peninsular (Vol. 1, pp. 411-417). Alicante: Museo de Aqueología de Alicante.

García-Puchol, O., Diez Castillo, A. A., \& Pardo-Gordó, S. (2017). Timing the western Mediterranean last hunter-gatherers and firs farmers. In O. García-Puchol \& D. C. Salazar-García (Eds.), Times of Neolithic transition along the western Mediterranean (pp. 69-100). New York: Springer.

Gassiot, E., Rodríguez, D., Pèlachs, A., Pérez, R., Julià, R., Bal-Serin, M. C., \& Mazzucco, N. (2014). La alta montaña durante la Prehistoria: 10 años de investigación en el Pirineo catalán occidental. Trabajos de Prehistoria, 71(2), 261-281.

Gassiot, E., Mazzucco, N., Obea, L., Tarifa, N., Antolín, F., Clop, X., ... Saña, M. (2015). La Cova del Sardo de Boí I l'explotació de l'alta muntanya als Pirineus occidentals en època neolítica. Tribuna d'Arqueologia, 2012-2013, 199-218.

Gassiot Ballbè, E., Mazzucco, N., Clemente-Conte, I., Rodríguez Antón, D., Obea Gómez, L., Quesada Carrasco, M., \& Díaz Bonilla. (2017). The Beginning of High Mountain Occupations in the Pyrenees. Human Settlements and Mobility from $18,000 \mathrm{cal} \mathrm{BC}$ to $2000 \mathrm{cal}$ BC. In J. Catalan, J. Ninot \& M. Aniz (Eds.), High mountain conservation in a changing world (pp. 75-105). New York: Springer.

Geddes, D. (1983). Neolithic transhumance in the Mediterranean Pyrenees. World Archaeology, 15(1), 51-66. doi: 10.1080/ 00438243.1983.9979884.

Grant, A. (1982). The use of tooth wear as guide to the age of domestic ungulates. In B. Wilson, C. Grigson, \& S. Payne (Eds.), Ageing and sexing animal bones from archaeological sites (pp. 91-109). Oxford: BAR British Series 109.

Hafez, E. S. E. (1952). Studies on the breeding season and reproduction of the ewe. Part I. The breeding season in different environments. Part II. The breeding season in one locality. Journal of Agricultural Science, 42, 13-231. doi: 10.1017/ S0021859600056896.

Halstead, P., Collins, P., \& Isaakidou, V. (2002). Sorting the sheep from the goats: Morphological distinctions between the Mandibles and Mandibular Teeth of adult Ovis and Capra. Journal Archaeology Science, 29(5), 545-553. doi: 10.1006/ jasc.2001.0777.

Helmer, D. (2000). Discrimination des genres Ovis et Capra à l'aide des prémolaires inférieures 3 et 4 et interprétation des âges d'abattage: L'exemple de Dikili Tash (Grèce). Anthropozoologica, 31, 29-38.

Helmer, D., Gourichon, L., Maamar, S., \& Vigne, J.-D. (2005). L'élevage des caprinés néolithiques dans le sud-est de la France: Saisonalité des abattages, relations entre grottes-bergeries et sites de plein air. Anthropozoologica, 40(1), 167-189.

Ioannidou, E. (2003). Taphonomy of animal bones: Species, sex, age and breed variability of sheep, cattle and pig bone density. Journal of Archaeological Science, 30(3), 355-365. doi: 10.1006/jasc.2002.0847.

Lancelotti, C., Balbo, A. L., Madella, M., Iriarte, E., Rojo, M., Royo, J. I., ... Peña-Chocarro, L. (2014). The missing crop investigating the use of grasses at Els Trocs, a Neolithic cave site in the Pyrenees (1564 m a.s.l.). Journal of Archaeological Science, 42, 456-466. doi: 10.1016/j.jas.2013.11.021.

Leizaola, F. (2008). Estrategias nutricionales de los pastores vascos: La cecina y otros alimentos de su dieta. Biblid, 3 , 209-222.

Llorente, L. (2015). Nuevas actividades de explotación de fauna en Cova Fosca (Ares del Maestrat, Castellón): Usos peleteros y consumo de carnívoros. In A. Sanchís \& J. L. Pascual (Eds.), Il Jornadas de Arqueozoología de Valencia (pp. 139-154). Valencia: Museu de Prehistòria de València-Diputación de València.

López-García, J. M., Blain, H.-A., Allué, E., Bañuls-Cardona, S., Bargalló, A., Martín, P., ... Oms, F. X. (2010). First fossil evidence of an "interglacial refugium" in the Pyrenean region. Naturwissenschaften, 97, 753-761.

Lyman, R. L. (1994). Vertebrate Taphonomy. Cambridge: Cambridge University Press.

Lyman, R. (2008). Quantitative Paleozoology. Cambridge: Cambridge University Press.

Mangado, X., Morales, J. I., Oms, F. X., Rey, M., \& Sánchez de la Torre, M. (2012). Estudio de los restos líticos de la Cova Colomera (Prepirineo de Lleida) entre 5220 y 1660 cal BC. Análisis arqueopetrológico de las materias primas silíceas y posibles áreas de captación. Rubricatum, 5, 155-161.

Martín, A., \& Vaquer, J. (1995). El poblament dels Pirineus a l'Holocè, del Mosolític a l'Edat del Bronze. In J. Bertrand-Petit \& E. Vives (Eds.), Muntanyes i Població: El passat dels Pirineus des d'una perspectiva multidisciplinària (pp. 35-72). Andorra La Vella: Société Préhistorique Française.

Martín, P., Saladié, P., Nadal, J., \& Vergès, J. M. (2014). Butchered and consumed: Small carnivores from the Holocene levels of El Mirador Cave (Sierra de Atapuerca, Burgos, Spain). Quaternary International, 353, 153-169. doi: 10.1016/ j.quaint.2014.08.011.

Martín, P., \& García-González, R. (2015). Identifying sheep (Ovis aries) fetal remains in archaeological contexts. Journal of Archaeological Science, 64, 77-87. doi: 10.1016/j.jas.2015.10.003. 
Martín, P., García-González, R., Nadal, J., \& Vergès, J. M. (2016). Perinatal ovicaprine remains and evidence of shepherding activities in Early Holocene enclosure caves: El Mirador (Sierra De Atapuerca, Spain). Quaternary International, 414, 316-329. doi: 10.1016/j.quaint.2015.08.024.

Mazzucco, N., Clemente-Conte, I., \& Gassiot, E. (2019). Lost in the mountains? The Cova del Sardo and the Neolithisation of the Southern Central Pyrenees (fifth-third mill. cal BC). Archaeological and Anthropological Sciences, 11(4), 1461-1475.

Metcalfe, D., \& Jones, K. T. (1988). A reconsideration of animal body-part utility indices. American Antiquity, 53, $486-504$.

Miracle, P. (2006). Neolithic Shepherds and their Herds in the Northern Adriatic Basin. In D. Serjeatson \& D. Field (Eds.), Animals in the Neolithic of Britain and Europe (pp. 63-94). Oxford: Oxbow Books.

Miralles, F., \& Tutusaus, J. (2005). Mil anys pels camins de l'herba. El llegat d'un món que s'acaba. Sabadell: Editorial Efadòs.

Mlekuž, D. (2006). Meat or milk? Neolithic economies of Caput Adriae. In Preistoria dell'Italia settentrionale. Studi in ricordo di Bernardino Bagolini Atti del Convegno, Udine settembre 2005 (453-458). Udine: Comune di Udine, Edizioni del Museo Friulano di Storia Naturale.

Mora, R., Benito-Calvo, A., Martínez-Moreno, J., González, P., \& De la Torre, I. (2011). Chrono-stratigraphy of the Upper Pleistocene and Holocene archaeological sequence in Cova Gran (south-eastern Pre-Pyrenees, Iberian Peninsula). Journal of Quaternary Science, 26(6), 635-644. doi: 10.1002/jqs.1486.

Nicod, P.-Y., Picavet, R., Argant, J., Brochier, J. L., Chaix, L., Delhon, C., ... Thiébault, S. (2008). La bergerie Néolithique de la Grande Rivoire. In J.-P Jospin \& T. Favrie (Eds.), Premiers bergers des Alpes: De la préhistoire à l'Antiquité (pp. 74-79). Gollion: Infolio, Gollion.

Noddle, B. (1974). Ages of epiphyseal closure in feral and domestic goats and ages of dental eruption. Journal of Archaeological Science, 1(1), 195-204. doi: 10.1016/0305-4403(74)90042-9.

Oms, F. X., Bargalló, A., Chaler, M., Fontanals, M., García, M. S., López, J. M., ... Vergès, J. M. (2008). La Cova Colomera (Sant Esteve de la Sarga, Lleida), una cueva-redil en el prepirineo de Lérida. Primeros resultados y perspectivas de futuro. In M. Hernández, J. A. Soler, \& J. A. López (Eds.), IV congreso del neolítico peninsular (Vol. I, pp. 230-236). Alicante: Museo de Arqueología de Alicante.

Oms, F. X., Petit, M. A., Morales, J. I., \& García, M. S. (2012). Le procesus de néolithisation dans les Pyrénées orientales. Occupation du milieu, culture matérielle et chronologie. Bulletin de la Société Préhistorique Française, 109(4), 651-670.

Oms, F. X., López-García, J. M., Mangado, X., Martín, P., Mendiela, S., Morales, J. I., ... Yubero, M. (2013). Hàbitat en cova i espai pels ramats ca. 6200-6000 BP: La Cova Colomera (Prepirineu de Lleida) durant el Neolític antic. Saguntum (P.L.A.V.), 45, 25-38.

Oms, F. X., Pedro, M., Morales, J. I., Allué, E., Frigola, J., Mendiela, S., ... Yubero, M. (2015). La Cova Colomera 30 anys després. Ocupacions humanes entre 6180-3280 BP al Congost de Mont-Rebei. Campanes de 2005-2011. In Primeres Jornades d'Arqueologia i Paleontologia del Pirineu i Arán. Coll de Nargó i la Seu d’Urgell, 29-30 noviembre de 2013 (pp. 116-123). Lleida: Diputació de Lleida.

Oms, F. X., Mestres, J., Cebrià, A., Morales, J. I., Nadal, J., Pedro, M., ... Fullola, J. M. (2016). La cova de la Guineu (Font-Rubí, Barcelona) i les relacions plana-muntanya al Penedès durant el neolític inicial. In H. Bonet \& B. Martín (Eds.), Del Neolític a l'Edat del Bronze en el Mediterrani occidental: Estudis en homenatge a Bernat Martí Oliver (Series de Trabajos Varios 119, pp. 97-108). Valencia: Museu de Prehistòria de València-Diputación de València.

Orengo, H., Palet, J. M., Ejarque, A., Miras, Y., \& Riera, S. (2014). Shifting occupation dynamics in the Madriu-Perafita-Claror valleys (Andorra) from the early Neolithic to the Chalcolithic: The onset of high mountain cultural landscapes. Quaternary International, 353, 140-152. doi: 10.1016/j.quaint.2014.01.035.

Payne, S. (1973). Kill-off patterns in sheep and goats: The mandibles from Aşvan Kale. Anatolian Studies, 23, 281-303. doi: $10.2307 / 3642547$.

Payne, S. (1985). Morphological Distinctions between the Mandibular Teeth of young Sheep, Ovis, and Goats, Capra. Journal of Archaeological Science, 12(2), 139-147. doi: 10.1016/0305-4403(85)90058-5.

Payne, S. (1987). Reference Codes for Wear States in the Mandibular Cheek Teeth of Sheep and Goats. Journal of Archaeological Science, 14(6), 609-614. doi: 10.1016/0305-4403(87)90079-3.

Pérez-Ripoll, M. (2006). El estudio arqueozoológico del Abric de La Falguera (Alcoi, Alacant). In O. García \& J. Aura (Eds.), El Abric de la Falguera (Alcoi, Alacant). 8000 años de ocupación humana en la cabecera del río Alcoy 2 (pp. 120-157). Alicante: Diputación Provincial de Alicante.

Prummel, W., \& Frisch, H. J. (1986). A guide for the distinction of species, sex and body side in bones of sheep and goat. Journal of Archaeological Science, 13(6), 567-577. doi: 10.1016/0305-4403(86)90041-5.

Riquelme, J. A. (1996). Contribución al Estudio arqueofaunístico durante el Neolítico y la Edad del Cobre en las Cordilleras Béticas: El Yacimiento arqueológico de Los Castillejos en Las Peñas de los Gitanos, Montefrío (Granada). (Tesis doctoral). Granda: Universidad de Granada.

Rodanés, J. M., \& Ramón, N. (1995). El Neolítico Antiguo en Aragón: Hábitat y Territorio. Zephyrus, XLVIII, 101-128.

Rojo, M., Peña, L., Royo, J. I., Tejedor, C., García, I., Arcusa, H., ... Alt, K. (2013). Pastores trashumantes del Neolítico Antiguo en un entorno de alta montaña: Secuencia crono-cultural de la Cova de Els Trocs (San Feliú de Veri, Huesca). BSAA Arqueología, LXXIX, 9-55. 
Rojo, M., Arcusa, H., Peña, L., Royo, J., Tejedor, C., García, I., ... Alt, K. W. (2014). Los primeros pastores trashumantes de la Alta Ribagorza. In I. Clemente-Conte, E. Gassiot, \& J. Rey (Eds.), Sobrarbe antes de Sobrarbe, pinceladas de historia de los Pirineos (pp. 127-152). Sobrarbe: Centro de Estudios de Sobrarbe.

Saladié, P., Rodríguez-Hidalgo, A., Díez, C., Martín-Rodríguez, P., \& Carbonell, E. (2013). Range of bone modifications by human chewing. Journal of Archaelogical Science, 40(1), 380-397. doi: 10.1016/j.jas.2012.08.002.

Sanchís, A., \& Sarrión, I. (2004). Restos de cánidos (Canis familiaris ssp.) en yacimientos valencianos de la Edad del Bronce. Archivo de Prehistoria Levantina, XXV, 161-198.

Santiago-Moreno, J., López-Sebastián, A., González-Bulnes, A., Gómez-Brunet, A., \& Chemineau, P. (2000). Seasonal changes in ovulatory activity, plasma prolactin, and melatonin concentration, in Mouflon (Ovis gmelini musimon) and manchega (Ovis aries) ewes. Reproduction, Nutrition, Development, 40, 421-430. doi: 10.1051/rnd:2000109.

Saña, M., Antolín, F., Alcántara, R., Sierra, A., \& Tornero, C. (2020). Integrating domesticates: Earliest farming experiences in the Iberian Peninsula. In K. J. Gron, L. Sorensen, \& P. Rowley-Conwy (Eds.), Farmers as the frontier: A pan European perspective on Neolithisation (pp. 161-176). Oxford: Oxbow Books.

Shipman, P., \& Rose, J. (1983). Evidence of butchery and hominid activities at torralba and ambrona. An evaluation using microscopic techniques. Journal of Archaeological Science, 10(5), 495-474. doi: 10.1016/0305-4403(83)90061-4.

Sierra, A., Bréhard, S., Montes, L., Utrilla, P., \& Saña, M. (2019). Sheep exploitation and husbandry in first farming societies: From production to consumption in Central Pyrenees in the Early Neolithic. Archaeological and Anthropological Sciences, $11,5813-5829$.

Sierra, A., Balasse, M., Rivals, F., Fiorillo, D., Utrilla, P., \& Saña, M. (2021). Sheep husbandry in the early Neolithic of the Pyrenees: New data on feeding and reproduction in the cave of Chaves. Journal of Archaeological Science: Reports, 37, 102935.

Solà, J. (2003). La muntanya oblidada. Economía tradicional, desenvolupament rural i patrimoni etnològic al Montsec. Barcelona: Generalitat de Catalunya.

Tejedor-Rodríguez, C., Moreno-García, M., Torneno, C., Hoffmann, A., García-Martínez de Lagrán, I., Arcusa-Magallón, H., ...Rojo, M. (2021). Investigating Neolithic caprine husbandry in the Central Pyrenees: Insights from a multi-proxy study at Els Trocs cave (Bisaurri, Spain). PLos One, 16(1), e0244139. doi: 10.1371/journal.pone.0244139.

Tornero, C., Balasse, M., Bréhard. S., Carrère, I., Fiorillo, D., Guilaine, J., ... Manen, C. (2020). Early evidence of sheep lambing de-seasoning in the Western Mediterranean in the sixth millennium BCE. Scientific Reports, 10, 12798.

Utrilla, P., \& Baldellou, V. (1996). Evolución diacrónica del poblamiento prehistórico en el valle del Cinca-Ésera. El registro de Olvena y otros yacimientos prepirenaicos. Bolskan, 13, 239-261.

Utrilla, P., \& Laborda, R. (2018). La cueva de Chaves (Bastarás, Huesca): 15,000 años de ocupación prehistórica. Trabajos de Prehistoria, 75(2), 248-269.

Vigne, J.-D. (2007). Exploitation des animaux et néolithisation en Méditerranée nord-occidentale. In J. Guilaine, C. Manen, \& J.-D. Vigne (Eds.), Pont de Roque-Haute. Nouveaux regards sur la néolithisation de la France Méditerranéenne (pp. 221-286). Toulouse: Archives d’Écologie Préhistorique.

Violant i Simorra, R. (1985). El Pirineo Español. Sant Adrià de Besòs: Editorial Alta Fulla.

Violant i Simorra, R. (2001). La vida pastoral al Pallars. Tremp: Garsineu Edicions.

von den Driesch, A. (1976). The measurement of animal bones from archaeological sites. Cambridge: Peabody Museum Press.

Zeder, M. A., \& Lapham, H. A. (2010). Assessing the reliability of criteria used to identify postcranial bones in sheep Ovis, and goats, Capra. Journal of Archaeological Science, 37(11), 2887-2905. doi: 10.1016/j.jas.2010.06.032. 